frequent results ; and this is often accompanied by a softening to a barely coherent sand or clay. Erroneous conclusions are thus frequently drawn from surface indications, as to the nature of the underlying rock.

The subject of the decay of rocks has re-
Smith, J. A. Tanner, M.D., and H. W. Eaton, Ph.D., Louisville - was not appointed till about three weeks before the close of the exposition : hence thorough tests were impossible.

As the U. S. company did not enter into the contest, there was no competition on the

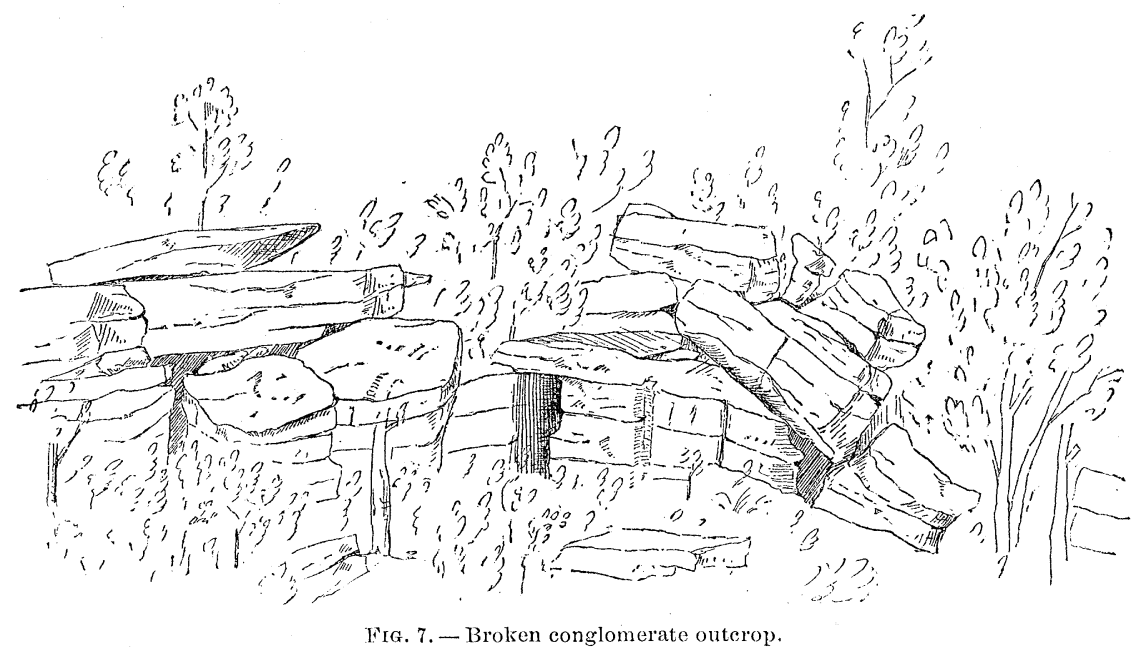

cently been admirably treated by Dr. T. Sterry Hunt, ${ }^{1}$ chiefly with regard to the crystalline rocks; and it deserves to be further studied, in the case of these more recent rocks, from its evident importance in chemical geology, its interesting and well-known relation to topography, and its economic bearing. Arthur Wrnslow.

Pennsylvania geological survey.

\section{ELECTRIC LIGHT TESTS AT THE LOUISVILLE EXPOSITION.}

The display of electric lights at the Louisville exposition, as to number, was the greatest ever made in and around one building. The number of lights used varied somewhat, but the average was about as follows:-

\begin{tabular}{|c|c|c|}
\hline & $\begin{array}{c}\text { Incandescent } \\
\text { lights. }\end{array}$ & $\begin{array}{l}\text { Arc- } \\
\text { lights. }\end{array}$ \\
\hline 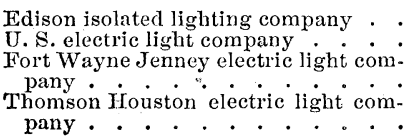 & $\begin{array}{r}4,600 \\
210 \\
-\end{array}$ & $\begin{array}{r}2 \overline{9} \\
100 \\
36\end{array}$ \\
\hline
\end{tabular}

The jury - consisting of Benjamin Rankin, Louisville; W. W. Weaver, Chicago ; Charles

1 The decay of rocks geologically considered. By T. Sterry Hunt, LL.D., F.R.S. American journal of science, September, 1883 . incandescent lights. However, the following tests were made: connection was made with a circuit containing 315 lights at what was considered an average point in the circuit; and fifteen lamps, five of them new and the balance selected systematically from the circuit while lighted, were tested in a specially constructed photometer-room while indicator-cards were being taken from the engine.

A Bunsen photometer with a twelve-foot bar was used, and the horizontal intensity determined with the carbon at an angle of $45^{\circ}$. The intensity of the (nominally) 16-candle lights varied from 12 to 19.66 candles, averaging 13.77 candles; and the average horsepower was 32.50. These figures give 9.70 lights, or 133.57 candles, per mechanical horsepower.

The action of the automatic regulator was then tested with a light in the photometer, first 50 and then 100 lights being thrown off and on. In one of the six cases the variation was 1.23 candles, but in all the others it was less than .66 of a candle. Only a momentary flicker was noticed as the lights were thrown off and on.

The jury reported as follows: "The tests of the Edison system are most satisfactory as to the efficiency of the various appliances, the steadiness of the light produced, and the general results. It is a matter worthy of note, that 
during the 100 days of the exposition, with over 4,000 lights burning, there was not at any time a suspension of light from failure of the appliances of the Edison electric lighting company."

Of the arc-lights, lamps were chosen, one at a time, from the circuits, and inserted in the same circuit in the photometer-room, care being taken that no change was made in the circuit adjustments. Indicator-cards were taken from the engine used, during the testing of each lamp. The strength of current, and fall in electromotive force, were also determined with an amperemeter and voltmeter; but, as only relative results were desired, these instruments were not graduated.

The photometer-bar was fifty feet long; and tests showed that there was no reflection vitiating the results, from the dead-black surface of the walls of the room. The photometric tests were made with an Edison incandescent light as a standard. Fifteen tests from candle to incandescent, and ten from incandescent to arc lights, were made for each lamp, five arclight tests being between the same number of tests of the standard.

The are-light was cut out during the tests of the standard, and a new cup was allowed to form before the next set of tests was made.

The dynamos were worked to their full advertised capacity in regard to the number of lights in the circuits; and four lights were tested in each case, with the following results :-

\begin{tabular}{|c|c|c|}
\hline & Jenney. & $\begin{array}{l}\text { Thomson } \\
\text { Houston. }\end{array}$ \\
\hline $\begin{array}{l}\text { Total number of lights in circuit . . . } \\
\text { Total mechanical horse-power . } \\
\text { Average horizontal intensity in candies } \\
\text { Average intensity per horse-power } \\
\text { Relative efficiency of lamps from light, } \\
\text { current, and fall in electromotive force. }\end{array}$ & $\begin{array}{l}16 \\
26.92 \\
496.5 \\
306.5 \\
\\
1.055\end{array}$ & $\begin{array}{l}12 \\
11.79 \\
291.8 \\
296.9\end{array}$ \\
\hline
\end{tabular}

From these tests, and an examination of the dynamos, lamps, regulators, etc., the awards were made as follows: to the Edison company, for isolated lighting, medals for the best incandescent system and light, and for the best dynamo and lamp for the incandescent light; to the Fort Wayne Jenney electric lighting company, medals for the best system and dynamo for arc-lighting; but, to the Thomson Houston electric lighting company, a medal for the best arc-light, because, "while the light of the Jenney was slightly stronger per horse-power of electrical energy used in the lamp, it was not quite so steady as the Thomson Houston." H. W. EATON.

\section{THE LATE MR. DARWIN ON INSTINCT. ${ }^{1}$}

AT the meeting of the Linnean society this evening (Dec. 6) a highly interesting posthumous paper on Instinct, by Charles Darwin, will be read and discussed. We have been favored with an early abstract of the same, which we here present to our readers.

After detailing sundry facts with reference to the migratory instincts of different animals, Mr. Darwin proceeds to suggest a theory to account for them. This theory is precisely the same as that which was subsequently and independently enunciated by $\mathrm{Mr}$. Wallace in Nature, vol. x. p. 459 . Thus, to quote from the essay: "During the long course of ages, let valleys become converted into estuaries, and then into wider and wider arms of the sea; and still $\mathrm{I}$ can well believe that the impulse [originally due to seeking food] which leads the pinioned goose to scramble northward would lead our bird over the trackless waters; and that, by the aid of the unknown power by which many animals (and savage men) can retain a true course, it would safely cross the sea now covering the submerged path of its ancient journey."

The next topic considered is that of instinctive fear. Many facts are given showing the gradual acquisition of such instinctive fear,. or hereditary dread, of man, during the period of human observation. These facts led Mr. Darwin to consider the instinct of feigning death, as shown by sundry species of animals, when in the presence of danger. Seeing that 'death is an unknown state to each living creature,' this seemed to him 'a remarkable instinct:' and accordingly he tried a number of experiments upon the subject with insects, which proved that in no one case did the attitude in which the animal 'feigned death' resemble that in which the animal really died; so that the instinct really amounts to nothing else, in the case of insects at all events, than an instinct to remain motionless, and therefore inconspicuous, in the presence of danger. From the facts given with regard to certain vertebrated animals, however, it is doubtful how far this explanation can be applied to them.

A large part of the essay is devoted to 'Nidification and habitation,' with the object of showing, by an accumulation of facts, that the complex instincts of nest-building in birds and of constructing various kinds of habitations by mammals, all probably arose by gradual stages under the directing influence of natural selection.

The essay concludes with a number of 'miscellaneous remarks' on instincts in general. First the variability of instinct is proved by sundry examples; next the fact of double instincts occurring in the same species; after which, "as there is often much difficulty in imagining how an instinct could first have arisen," it is thought "worth while to give a few out of many cases of occasional and curious habits, which cannot be considered as regular instincts, but which might, according to our views, give rise to

\footnotetext{
1 From Nature of Dec. 6.
} 